\title{
KEDUDUKAN PEREMPUAN DALAM HINDUISME
}

\author{
Ida Bagus Made Satya Wira Dananjaya \\ Fakultas Ilmu Sosial dan Ilmu Politik, Universitas Mahendradatta, Denpasar \\ e-mail: gus_danajaya@yahoo.com
}

\begin{abstract}
Abstrak - Perempuan merupakan jenis kelamin yang paling banyak mendapatkan sorotan di Dunia dibandingkan dengan lawan jenisnya yaitu laki-laki. Peta kognitif "tentang perempuan" seakan menjadi viral di semua jaman. Hardiman mencatat kondisi dan posisi perempuan pada masa pra-sejarah terkait dengan persepsi dan pembagian kerja berasas gender jauh lebih egaliter dibandingkan awal abad masehi sampai sekarang. Perempuan pada masa pra-sejarah dipersepsikan sama dengan laki-laki, kendati telah masuk ranah domestic pekerjaan rumah tangga bagi perempuan hanya bersifat temporal-posisional. Perempuan dipilih untuk menjaga anak, meramu makanan karena diperlukan tenaga untuk itu, singkatnya tidak ada eksploitasi.

Begitu juga Fromm menyatakan sebelum masa Patriarchate muncul perempuan walaupun mengerjakan pekerjaan domestic tetapi posisi sosialnya tidak bersifat asimetris. Seiring perkembangan jaman di hampir setiap Negara dimulai pada abad ke-17 terjadi pemberontakan intelektual terhadap posisi social perempuan. Inggris, Prancis, Amerika mengawali gerak intelektual melalui puisi, cerpen, perkumpulan perempuan dan di Indonesia gerakan ini dimualai oleh R.A Kartini, Dewi Sartika, Goesti Ayu Rai dll. Perempuan merasa kedudukannya tidak sama dengan laki-laki, hal tersebut membawa ekses lemahnya posisi sosialnya, pembagian kerja berbasis gender lebih bersifat eksploitatif ketimbang temporal-posisional. Uraian ringkas tersebut membawa suatu rumusan pertanyaan, apakah agama membawa dampak positif bagi posisi social perempuan di masyarakat?. Tulisan ini ingin memberikan salah satu jawaban berupa argumentasi mengenai kedudukan perempuan dalam agama Hindu.
\end{abstract}

Kata kunci : perempuan, hindu, gender

Abstract - Women are the sex that gets the most attention in the world compared to the opposite sex, namely men. Cognitive maps "about women" seemed to be viral in all ages. Hardiman noted that the condition and position of women in pre-historic times related to the perception and division of gender-based work was far more egalitarian compared to the beginning of the century until now. Women in pre-history times are perceived to be the same as men, even though it has entered the domestic domain domestic work for women is only temporal-positional. Women are chosen to look after children, gather food because it requires energy for it, in short there is no exploitation.

Likewise Fromm stated that before the Patriarchate period women appeared despite working on domestic work but their social position was not asymmetrical. As the times progressed in almost every country beginning in the 17th century there was an intellectual rebellion against women's social position. Britain, France, America initiated intellectual movement through poetry, short stories, women's associations and in Indonesia this movement was initiated by R.A Kartini, Dewi Sartika, Goesti Ayu Rai etc. Women feel that their position is not the same as that of men, this brings the excess of their weak social position, gender-based division of labor is more exploitative than temporal-positional. This brief description brings a question formulation, does religion have a positive impact on women's social position in society? This paper wants to provide one answer in the form of argumentation about the position of women in Hinduism.

Keywords :women, hinduism, gender 


\section{Perempuan Masa Pra-Arya di India}

Kenapa disebut pra-Arya bukan pra-Hindu ? Phalgunadi (2010) dan Majmundar (1944) memberi jawaban peradaban pra-arya di lembah sungai Sindhu, Mahendjo daro-Harrapa (selanjutnya disebut peradaban pra-Arya) mewarnai perkembangan Hinduisme selanjutnya. Peradaban pra-Arya dikelompokan oleh peneliti Barat sebagai peradaban tinggi, sama halnya dengan Mesopotamia, Mediteranian, Yunani, Romawi. Pencapaian mengenai tata wilayah, konsep subsistensi, dan kehidupan social yang tergolong rapi dan teratur. Mengenai kedudukan perempuan tidak banyak peninggalan yang diketahui membahas kedudukan perempuan, namun dari agama pra-Arya dapat ditemukan kedudukan perempuan dalam masyakat pra-Arya di lembah sungai Sindhu.

Pemujaan Dewi Ibu (Mother Goddes) membuka peta kognitif tentang perempuan. Dewi Ibu sebagaimana Phalgunadi, Majmundar, Zimmer, Muller menyatakan sebagai Dewi Alam atau kesuburan. Berbagai tanda dalam tubuh Dewi Ibu yang ditemukan dalam sebuah seal (?) diidentikkan dengan kesuburan (Payudara besar, dan bulu lebat) serta adanya gambar pohon besar menegaskan Dewi Ibu sebagai Dewi alam semesta. Selain itu sebuah gambar mengenai korban binatang di sebuah seal terdapat gambar perempuan yang sedang memuja. Redig menguaraikan perempuan menjadi objek pemujaan dengan daya naturalnya sekaligus subjek pemuja dengan daya magi yang dimilikinya. Pemujaan terhadap Dewi Ibu menandakan kedudukan perempuan yang sacral dengan daya naturalnya sekaligus juga sebagai pemimpin ritual bersama laki-laki (bandingkan dengan Pemangku Perempuan sebagai satu-satunya pemimpin ritual pada masa lalu sampai masa pra-kemerdekaan di Desa Sidetapa dan Tigawasa).

\section{Perempuan dalam Pandangan Vedik (Peradaban Arya)}

Tidak banyak pemujaan Dewi ditemukan pada peradaban Arya namun seiring perkembangan penyerapan kebudayaan lembah sungai Sindhu membawa perubahan pandangan terhadap perempuan, terlebih dengan adanya pemujaan terhadap Kali, Durga, dan perkembangan khazanah tantrisme. Amstrong (2010) mencatat dalam the Great Transformation Arya merupakan gelar kehormatan bagi suku-suku mencapai peradaban tinggi sekaligus dalam kebudayaan spiritual. Dalam berbagai catatan perjalanan bangsa Arya dengan membawa kebudayaan Wedik memberikan khasanah baru bagi wilayah yang di datanginya termasuk pandangannya mengenai kedudukan social perempuan.

Pandangan bangsa arya tentang kedudukan perempuan harus juga dilihat darikonteks historisitasnya. Kesimpulan Saraswati (1977) begitu juga dengan Putra karena konteks ruang laki-laki mendapatkan otoritas public dan kewilayahan yang jauh lebih tinggi dari perempuan. Namun keberadaan perempuan dalam suatu keluarga merupakan bentuk kesucian keluarga. Pemberontakan perempuan merupakan suatu aib besar bagi keluarga Arya. Kebahagiaan perempuan adalah suatu tanda keberhasilan keluarga. Dalam ritual perempuan mayoritas teks wedik menguraikan perempuan mendapatkan posisi penting. Dalam Weda pemujaan terhadap aspek feminis ditunjukan dalam porsi yang kecil sebagai Dewi Soma dan Saraswati. Dengan diterimanya pengetahuan peradaban sungai Sindhu kedudukan perempuan mendapatkan porsi yang lebih (terlepas dari adat India yang Kaku dengan distorsi kastanya) terlihat dari diterimanya Atharwa Weda sebagai Weda keempat. Begitu juga dengan memasuki jaman Purana, perempuan mendapatkan kedudukan yang cukup mulia bagi sekte-sekte tertentu termasuk dalam khazanah tantrisme yang memasuk- 
kan Shakti sebagai sentrum energy semesta.

Tokoh teologi Sati, Kali, Saraswati, Laksmi, Parwati menegaskan perempuan dalam Wedik sebagai sumber kebahagiaan, kesucian dan energy bathin keluarga. Kendati masih bercorak domestic namun penghormatan perempuan setiap pagi yang ditujukan bagi para dewa adalah awal dari anugrah keluarga dari para Dewa. Perempuan adalah pemimpin upacara pagi disetiap rumah tangga di batharawarsa sebelum memualainya aktivitas keluarga.

Perempuan dalam Teks-teks Hinduisme lainya

Titib dalam buku Citra Wanita, begitu juga Darmayasa dan Arwati yang banyak mengutip Manawa Dharmasastra (cari slokanya nggh mbok in, klo ga salah Bab III atau Bab IV)menyimpulkan perempuan sebagai sosok penting dalam kesucian, kerohanian keluarga Hindu. Bahkan dalam teks Mahabaratha sosok Kunti dan Drupadi menjadi pilar egaliterisasi gender. Kunti adalah pemimpin keluarga yang membawahin panca pandawa yang dalam kebudayaan semitik jarang terjadi. Kunti layaknya ayah dalam keluarga patriarki memiliki otoritas penuh dalam setiap keputusan dan tetap menjaga kesuciannya (terlepas dari anugrah surya berupa karna). Hal tersebut member argumentasi bahwa perempuan juga dapat menjadi kepala keluarga, bahkan disetiap keputusan Raja Pandu ada nafas kunti di dalamnya.

Drupadi adalah sosok feminis perkasa begitu tulis Wedakusuma (Filolog UNUD) dalam artikel internasionalnya tentang Drupadi dan Calonarang. Siapa yang dapat menyamai Drupadi, bersuami lima dan sangat teratur serta adil. Drupadi adalah pendobrak tembok budaya patriarchal dan memberikan angin segar bagi perempuan bahwa poliandri adalah sepadan dengan poligini. Corak agama semitik yang patriarchal absolute member dampat pada lemahnya modal social perempuan, tapi ditangan drupadi hal tersebut diputar balikkan. Inilah asumsi logis dari Wedakusuma bahwa Drupadi adalah feminis perkaya, poligami yang menjadi otonomi laki-laki diberontak oleh Drupadi menjadi milik bersama (asal adil) dan tidak melupakan stri sasana (isinya tyang lupa, bukunya entah kemana).

Dalam teks Sarasamusscaya bagian stri perempuan bersifat problematic bagi laki-laki, begitu kesimpulan Arniati dalam tesisnya tentang kedudukan perempuan. Dengan mengutif sloka-sloka sarasamusccaya Arniati menyimpulkan kedudukan yang rendah bagi perempuan mirip agama semitik (cari slokanya bagian akhir sarasamusccaya mbok in). namun dalam pembelaannya Ida Pedanda Sakti Telabah, begitu juga Arwati dan Tjok Sudharta menggariskan sarasamusccaya adalah teks yang sengaja dibuat untuk laki-laki bagi mereka melaksanakan ajaran muni secara penuh, sehingga realitas dunia termasuk perempuan dianggap sekedar benda.

Kesimpulan

Pembedaan kerja berasas gender dimulai pada masa prahistoris namun tidak bercorak eksploitatif, yaitu temporal-posisional harus ada yang menempati posisi domestik. Agama pra-arya menempatkan posisi perempuan setara dengan laki-laki khazanah teologi. Masyarakat melakukan industry melakukan genderisasi pekerjaan public secara eksploitatif (teori feminis Marx, Allthuser, ). Dalam peta kognisi Hinduisme perempuan dapat menjadi pemimpin rumah tangga, ritual sekaligus melakukan egaliterisasi terhadap poligami. Wiana (1997) dengan mengambil istilah dalam Manawadharmasastra pelaksanaan keagamaan Hindu harus sesuai dengan konsep "nutana" yaitu peremajaan sesuai dengan konteks ruang dan waktu. 